\title{
The JIBS 2017 Decade Award: The determinants of Chinese outward foreign direct investment
}

\author{
Alain Verbeke \\ Haskayne School of Business, University of \\ Calgary, Calgary, Canada \\ Correspondence: \\ A Verbeke, Haskayne School of Business, \\ University of Calgary, Calgary, Canada \\ e-mail: alain.verbeke@haskayne.ucalgary.ca
}

Journal of International Business Studies (2018) 49, I-3. https://doi.org/ | 0.1057/s4 I 267-0 I 7-0 I 30-8

The Selection Committee for the JIBS Decade Award was pleased to recommend the presentation of the 2017 JIBS Decade Award, recognizing the most influential article published in JIBS 10 years ago, to Peter J. Buckley, L. Jeremy Clegg, Adam R. Cross, Xin Liu, Hinrich Voss, and Ping Zheng (all at the Centre for International Business, Leeds University Business School, UK, at the time of publication), for their 2007 article, "The determinants of Chinese outward foreign direct investment" (JIBS, 38(4): 499-518).

The award, sponsored by JIBS' publisher Palgrave Macmillan, is designed to recognize the most influential paper published in JIBS 10 years prior and is presented at the annual AIB conference. In order to be considered for the JIBS Decade Award, an article must be one of the five most cited articles published in JIBS for the year being considered.

The 2017 Selection Committee members were Gabriel R.G. Benito (Chair), AIB Program Chair Sarianna Lundan, and immediate past AIB Program Chair Charles Dhanaraj. JIBS Editor-in-Chief Alain Verbeke was an ex officio, non-voting committee member. The Selection Committee examined total citations, total number of journals citing the paper, and total number of leading journals (excluding JIBS) citing the paper to determine the top five most cited articles. The Committee read and discussed the top five nominees and then voted on the winning article.

In recommending the award-winning article, the Committee noted that: "Buckley et al. (2007) was among the pioneering empirical studies of Chinese outward foreign direct investment (OFDI), and broadly from the emerging countries. It was originally published in a focused issue of JIBS entitled 'International Expansion of Emerging Market Businesses' (guest edited by Rosalie L. Tung and Yadong Luo) that included several of the most impactful 
articles published in the journal in 2007. In fact, the 2007 JIBS-focused issue comprised five out of the 10 most cited articles over the last decade.

"Buckley and his colleagues provide a truly comprehensive treatment of Chinese investment abroad making it a landmark study in understanding OFDI. The study spans three decades of OFDI going all the way back to the first few investments in the early 1980s when China introduced its 'open doors' policy, taking its first cautious move towards internationalization. The study goes all the way into the 2000s when the 'go global' policy was implemented.

"While standing firmly on received theory of foreign direct investment, the framework used in the study includes a relatively broad set of variables, suitably matching the unique context of Chinese OFDI, and by extension also possibly OFDI from other emerging countries. While the main empirical part of the study is statistical, it also includes a fairly detailed historical overview, thereby providing an unusually rich depiction of the empirical setting.

"The study was among the first of its kind to tackle the measurement and estimation issues related to Chinese OFDI, and as such it served to establish a very useful template for empirical research in the following years. Despite being an empirical study, with these types of studies often lagging behind conceptual articles in citations, Buckley et al. (2007) has gained a wide impact as measured by the scholarly citations (data from the Web of Science), from popular Google Scholar citations, as well as the number and breadth of the journals that have cited the article. The original empirical research has spawned several new studies in multiple countries and brought in new attention to the topic of outward FDI. The innovativeness of the paper is that while most of the studies on emerging markets such as China were focused on inward FDI, Buckley and his associates drove the field's attention to broaden its scope to OFDI from emerging countries.

"For all these reasons, the selection committee recommends the Buckley et al. (2007) paper, which has become a widely cited and highly impactful article, for the 2017 JIBS Decade Award."

Buckley et al.'s (2007) paper allowed 'nesting' the specificities of Chinese OFDI in mainstream internalization theory. It demonstrated the close alignment between macro-level institutional changes, supporting especially the international expansion of state owned enterprises - SOEs, and micro-level, firm-specific advantages - FSAs underlying such successful expansion. In conceptual terms, Chinese OFDI has been used as a policy instrument to link home country-specific advantages (CSAs) with both host CSAs and capabilities held by foreign firms. The key difference with predictions from mainstream internalization theory was that Chinese multinational enterprises (MNEs), whether SOEs or private companies viewed as national champions, were almost incidental 'diamond connectors,' rather than the driving force behind the resulting linkages among national diamonds. It was not home country institutional quality either that provided the key foundation for international expansion, but rather pro-active government policies, supported by extensive financial resources sheltered from the discipline of financial markets.

The question arises whether the dominance of such government-led, visible hand is likely to serve economic efficiency in the long run, and whether it will ultimately be reflected in artful resources orchestration, innovation, and the crafting of dynamic capabilities, comparable to what can be observed in firms free from such government guidance. In the realm of foreign acquisitions, one can easily understand the benefits from central guidance that would accrue to the Chinese economy. Such benefits might include contributions to macro-level resources security, reverse knowledge transfers, control of foreign operations to serve the Chinese market, and even financial portfolio benefits. But it is more difficult to expect out of a base of national champions, the rise of flexible international networks that can achieve sustained competitive advantage, building upon novel resource combinations and related non-location bound FSAs.

The past decades have shown a scarcity - rather than the abundance - of corporate globalization from developed economies. Even there, misguided and unfounded advice has sometimes been dispensed to the few global firms in existence that good strategy entails supporting governments towards redistributive, macro-level income policies, and other social endeavors. Such goals, however, should not be pursued systematically by internationally operating firms, for the simple reason that these companies mostly lack any true expertise on matters of redistribution and social justice.

In parallel with the above, long-term, successful corporate globalization requires specialized entrepreneurial judgment to exploit, augment, and rejuvenate extant, micro-level FSA stocks. This 
requirement does not change whether a firm operates out of a developed economy, or an emerging one such as China. In emerging economies, corporate globalization pursued through the visible hand of well-meaning government agencies, but fraught with challenges of bounded rationality and bounded reliability, is unlikely to succeed, especially as geographic diversification widens. The frailties observed in the Chinese OFDI decisionmaking processes and the related performance outcomes, further highlight that MNEs always do need an initial pool of FSAs, especially in the realm of sound managerial practices, and effective recombination with resource bundles abroad, to achieve international corporate success.

It is therefore reasonable to predict a two-sided, future trajectory of Chinese OFDI. One side will see SOEs and private-owned national champions' continued adherence to public policy goals that may occasionally coincide with outcomes of economic efficiency and optimal value creation. The second side, which may be more promising from a corporate globalization perspective, will see Chinese entrepreneurs enter foreign markets based on their business judgment and their companies' FSAs, following the rules of 21st century, social market capitalism. If increases in investment and trade are truly to contribute to the peaceful integration of nations, one can hope that this second side of Chinese OFDI will gain in significance.

At the AIB Annual Meeting in Dubai in June 2017, Professors Buckley, Clegg, Cross, and Voss, along with invited discussants Exequiel Hernandez (University of Pennsylvania) and Ravi Ramamurti (Northeastern University), made a retrospective presentation of the work and discussed where the field has progressed and where it should go next in studying multinationals and outward foreign direct investment.

What follows in this issue are the authors' written Retrospective, together with the discussants' and co-authors' Commentaries, based on that AIB 2017 session. For the original 2007 article, please visit www.jibs.net, where it is free to download, along with all other past Decade Award winners. 